УДК 352:351.88

\title{
ОЦІНКА ЕФЕКТИВНОСТІ ДІЯЛЬНОСТІ ОРГАНІВ МІСЦЕВОГО САМОВРЯДУВАННЯ

$$
\begin{gathered}
\text { EVALUATION OF EFFICIENCY } \\
\text { OF LOCAL GOVERNMENT BODIES }
\end{gathered}
$$

\author{
Носань Наталія Сергіївна \\ кандидат історичних наук, доцент, \\ Черкаський національний університет імені Богдана Хмельницького \\ ORCID: https://orcid.org/0000-0002-4005-8333 \\ Кусяка Мар'яна Олександрівна \\ студентка, \\ Черкаський національний університет імені Богдана Хмельницького \\ ORCID: https://orcid.org/0000-0002-2762-3588
}

\author{
Nosan Natalia, Kusaka Mariana \\ Cherkassy National University named after Bohdan Khmelnytsky
}

\begin{abstract}
Робота присвячена дослідженню основних підходів до оцінки ефективності діяльності органів місцевого самоврядування. Проаналізовано основні фрункції органів місцевої влади: надання муніципальних послуг населенню; управління комплексним соціально-економічним розвитком території; управління місцевим господарством. Досліджено основні види ефективності діяльності органів місцевого самоуправління. Надане авторське визначення поняття «есрективність муніципального управління». Зроблено аналіз зарубіжного і вітчизняного досвіду фрормування систем оцінки ефективності діяльності органів місцевого самоврядування та здійснено їх класифрікацію з метою вибору оптимального варіанту. В результаті дослідження діючої в Україні методики оцінки ефективності діяльності органів місцевого самоврядування було виявлено ряд недоліків.

Ключові слова: ефективність, державне управління, місцевий розвиток, місцеве самоуправління, органи державної та місцевої влади.
\end{abstract}

Работа посвящена исследованию основных подходов к оценке эфффективности деятельности органов местного самоуправления. Проанализированы основные фуунцци органов местной власти: предоставление муниципальных услуг населению; управления комплексным социально-экономическим развитием территории; управления местным хозяйством. Исследованы основные виды эфффективности деятельности органов местного самоуправления. Предоставлено авторское определение понятия «эфорективность муниципального управления». Сделан анализ зарубежного и отечественного опыта формирования систем оценки эффрективности деятельности органов местного самоуправления и осуществлена их классификация с целью выбора оптимального варианта. В результате исследования действующей в Украине методики оценки эфрфективности деятельности органов местного самоуправления был выявлен ряд недостатков.

Ключевые слова: эффрективность, государственное управление, местное развитие, местное самоуправление, органы государственной и местной власти.

In Ukraine, the effectiveness of local governments is currently being actively discussed at all levels of government and in the scientific community. The results of modern research show that, despite constant innovations, the current system of evaluating the effectiveness of local government is not without its shortcomings. Awareness of the high degree of importance of the problem of evaluating the effectiveness of local government, the shortcomings of the existing methodology for evaluating efficiency, the need to eliminate them and the formation of an effective system for evaluating the effectiveness of local governments determine the relevance of this study. The purpose of the study is to study the main approaches to assessing the effectiveness of local governments. The theoretical and methodological basis of the study were the scientific works of domestic and foreign researchers on the nature of the institution of local government, as well as the problems of effective management of municipalities, regulations of Ukraine. The main functions of local authorities are analyzed in the work: provision of municipal services to the population; management of complex socio-economic development of the territory; local economy management. The main types of efficiency of local self-government bodies are investigated. The author's definition of the concept "ef- 
ficiency of municipal management" is given. An analysis of foreign and domestic experience in the formation of systems for assessing the effectiveness of local governments and their classification in order to select the best option. As a result of the study of the current methodology in Ukraine for assessing the effectiveness of local governments, a number of shortcomings were identified. The proposed method of calculating a comprehensive indicator for assessing the effectiveness of local governments is a set of differentiated and unified approach. The combination of these approaches, as well as taking into account the development of each settlement that is part of the municipal district, will assess the activities of local governments more objectively and will help eliminate vulnerabilities, as it depends on the effectiveness of local government.

Keywords: efficiency, public administration, local development, local self-government, state and local authorities.

Постановка проблеми. Безліч приватних проблем місцевого самоврядування представляють собою похідну від такої загальної та актуальної проблеми як ефективність державного і місцевого управління. У більшості розвинених зарубіжних країн підвищенню ефрективності діяльності органів влади та ії оцінці приділяється значна увага. Більш того, визнається, що ефрективне державне і місцеве управління $€$ однією з умов забезпечення сталого соціально-економічного розвитку територій та поліпшення добробуту населення.

В Україні в даний час питання ефективності органів місцевого самоврядування активно обговорюються на всіх рівнях управління і в науковому середовищі. Результати сучасних досліджень свідчать про те, що, незважаючи на постійні нововведення, діюча система оцінки ефективності місцевої влади не позбавлена недоліків. При фрункціонуванні органів місцевого самоврядування в умовах існуючої методики оцінки ефрективності державні службовці та особи, які заміщають державні посади на постійній основі, прагнуть до формального досягненню показників, а не до підвищення ефрективності своєї роботи.

Усвідомлення високого ступеня важливості проблеми оцінки есрективності роботи місцевої влади, наявність недоліків в існуючій методиці оцінки ефрективності, необхідність їх усунення і фрормування дієвої системи оцінки ефрективності діяльності органів місцевого самоврядування обумовлюють актуальність даного дослідження.

Аналіз останніх досліджень і публікацій. Значний внесок у теорію ефективності управління внесли П. Друкер, Ф. Тейлор, А. Файоль, Г. Саймон та інші дослідники.

Проблемам підвищення есрективності діяльності органів державної влади присвячені праці В. Бакуменка, С. Дубенка, В. Князєва, Н. Нижника та інших авторів.

Питання фрункціонування органів місцевого самоврядування та розвитку місцевих утворень в своїх дослідженнях розглядали М. Баймуратов, Ю. Панійко, М. Пухтинський, В. Кравченко, Ю. Чудновський та інші.
Виділення невирішених раніше частин загальної проблеми. Незважаючи на високу значимість даного питання для сучасної України, фундаментальні дослідження з проблем оцінки ефрективності діяльності органів місцевої влади практично відсутні, а існуючі праці вчених присвячені загальним питанням ефрективності місцевого управління та аналізу результатів оцінки ефективності за діючою методикою. Наявність даного пробілу в такій важливій галузі знань в сфрері місцевого управління зумовило наукову і практичну значимість виконання дослідження.

Формулювання цілей статті. Метою дослідження $€$ дослідження основних підходів до оцінки ефективності діяльності органів місцевого самоврядування.

Виклад основного матеріалу. Незважаючи на актуальність проблеми ефективності органів місцевого самоврядування, підходів до визначення даної категорії не багато. Найчастіше в основі процесу визначення ефективності лежить цільовий підхід (ступінь досягнення поставлених цілей суб'єктом управління). Однак при визначенні ефективності місцевого управління не менш важливим $€$ фрункціональний підхід, який передбачає розмежування областей оцінки есрективності в залежності від фрункцій органів місцевого самоврядування.

Вивчення думок теоретиків місцевого управління 3 питання природи органів місцевого самоврядування, а також дослідження основних повноважень органів місцевого самоврядування, закріплених законодавчо, дозволило виділити наступні основні фрункції органів місцевої влади [1; 2]:

- надання муніципальних послуг населенню;

- управління комплексним соціально-економічним розвитком території;

- управління місцевим господарством.

Таким чином, при оцінці ефективної діяльності органів місцевого самоврядування необхідний облік таких видів ефективності (рис. 1).

Діяльність органів місцевого самоврядування можна назвати ефеективною тоді, коли 
вона есрективна на всіх етапах управління соціально-економічним розвитком муніципального утворення, починаючи від вибору цілей і визначення завдань, закінчуючи отриманням результатів їх реалізації. Грамотне управління місцевим господарством і розвиток основних складових даної сфрери також $€$ показником есрективності місцевої влади. Крім цього, якість надаваних населенню муніципальних послуг лежить в основі ефективної діяльності органів місцевого самоврядування.

Таким чином, параметри оцінки ефективності повинні враховувати специсріку місцевого самоврядування, його соціальну природу, виходити з фрункцій, повноважень і наявних ресурсів.

Відповідно до вище сказаного нами зроблена спроба надати власне визначення поняття «ефрективність муніципального управління». На нашу думку, це характеристика процесу впливу суб'єкта управління (органів місцевого самоврядування) на об'єкт управління в цілому (муніципальне утворення) і його складові частини (муніципальне господарство, містоутворюючу базу тощо), при якому останні переходять в новий стан (відбувається поліпшення параметрів об'єкта управління). Суб'єкт управління при такому впливі не виходить за встановлені рамки використання наявних ресурсів (орінансових, людських, часових тощо). Слід зазначити, що процес впливу органів місцевого самоврядування на об'єкт управління не є спонтанним. Він відбувається відповідно до закріплених програмами розвитку муніципального утворення і підпорядковується стратегічній меті, яка, в свою чергу, повинна бути спрямована на задоволення потреб місцевої громади, покращення якості та підвищення рівня життя населення.
Вивчення зарубіжного і вітчизняного досвіду фрормування систем оцінки ефективності діяльності органів місцевого самоврядування дозволило здійснити їх класифрікацію 3 метою вибору оптимального варіанту.

В сучасній науковій думці наявні два способи формування системи оцінки: активний і пасивний. У першому випадку ініціатива щодо запровадження системи оцінки виходить від муніципального рівня в цілому або конкретного муніципалітету (США, Канада, Німеччина), у другому - регламентується на державному рівні (Росія, Нова Зеландія, Великобританія) [3].

Крім того, можна класифрікувати саму систему оцінки в залежності від показників які входять до її складу: унісрікована система оцінки, при якій аналіз рівня ефективності діяльності органів місцевого самоврядування здійснюється на основі єдиного для всіх муніципальних утворень набору показників, особливості конкретного муніципалітету не враховуються (Росія, Німеччина, Великобританія); диференційована система оцінки, яка формується на муніципальному або регіональному рівні з урахуванням умов фрункціонування муніципалітету або стратегічних цілей його розвитку (США, Канада, Нова Зеландія, Японія, Китай) [3].

Розглянуті приклади систем оцінки есрективності діяльності органів місцевого самоврядування муніципальних утворень зарубіжних країн дозволили зробити висновок, що найбільш результативним $€$ варіант, при якому органи місцевого самоврядування самостійні у виборі показників оцінки своєї діяльності 3 урахуванням умов розвитку наданої їм території і її стратегічних цілей, а органи державної влади позначають лише загальні контури політики в області підвищення ефрективності місцевого управління.

Область оцінки ефективності

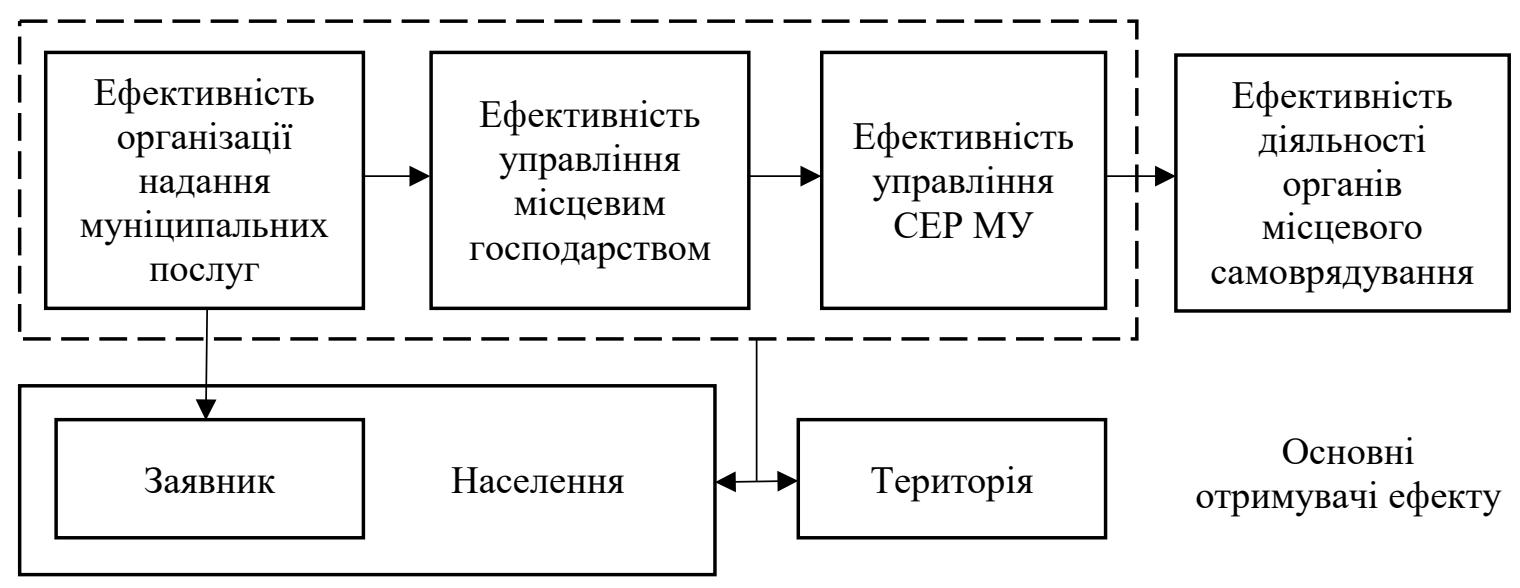

Рис. 1. Види ефективності діяльності органів місцевого самоуправління 
В результаті дослідження діючої в Україні методики оцінки ефективності діяльності органів місцевого самоврядування було виявлено ряд недоліків, до числа найбільш значущих належать [4]:

- прагнення органів місцевого самоврядування до фрормального досягненню показників, а не до підвищення ефективності своєї роботи («робота на показник»);

- уніфрікованість офріційної методики, що не дозволяє враховувати умови розвитку конкретного муніципального утворення;

- негативні причинно-наслідкові зв'язки між показниками оцінки ефективності.

Результати дослідження проблем фрункціонування і тенденцій розвитку існуючої методики оцінки ефективності діяльності органів місцевого самоврядування дозволили зробити висновок про те, що процес управління ефрективністю в цілому і механізм оцінки зокрема вимагають значного доопрацювання.

Базовою проблемою української системи оцінки ефективності діяльності органів місцевого самоврядування $€$ їі існування поза будь-якою більш загальною системою такою, як система управління ефективністю. Оцінка есрективності як ізольований процес не відповідає очікуванням населення і місцевих службовців, зацікавлених в досягненні результатів. В даний час оцінка ефективності - не що інше, як механізм збору інфоормації про основні результати розвитку деяких підсистем муніципального утворення, в той час як система оцінки ефективності повинна бути ланкою в ланцюзі процесу управління еорективністю. До теперішнього часу з такої позиції процес управління есрективністю діяльності органів місцевого самоврядування не розглядався [5].

На нашу думку, управління ефрективністю діяльності органів місцевого самоврядування це система, що складається 3 організаційних процесів, які дозволяють органам місцевого самоврядування визначити стратегічні цілі та потім оцінювати і управляти діяльністю по досягненню поставлених цілей при оптимальному використанні наявних ресурсів.

До системи показників оцінки ефрективності, на нашу думку, відносяться:

1) Функціональний аспект. Всі показники системи розбиті на три блоки в залежності від основних фуннкцій органів місцевого самоврядування: показники оцінки ефективності надання муніципальних послуг; показники оцінки ефрективності управління муніципальним господарством; показники оцінки ефек- тивності управління соціально-економічним розвитком території.

2) Введення показників локального (поселенського) рівня. Діюча методика оцінки ефрективності не передбачає оцінку діяльності такого важливого інституту як органи місцевого самоврядування поселень. Запропонована методика усуває цю прогалину.

3) Наявність індивідуальних показників (дисреренційований підхід). Крім обов'язкових для всіх муніципальних утворень регіону показників, пропонується введення переліків індивідуальних показників, залежних від слабких місць території і цілей комплексного соціально-економічного розвитку муніципальних утворень.

4) Облік повноважень та предметів управління органів місцевого самоврядування. Загальна логіка розрахунку комплексного показника оцінки ефективності діяльності органів місцевого самоврядування муніципального району (міського округу) показана на рис. 2.

Врахування специфріки конкретної території при визначенні показників оцінки ефрективності не означає, що повний перелік показників повинен фрормуватися на рівні муніципального району або на локальному рівні. Повністю відмовитися від уніфрікованості неможливо, так як існує ряд блоків оцінки, що не залежать від умов розвитку конкретної території. До таких блоків відносяться: організація надання муніципальних послуг та виявлення громадської думки місцевої громади 3 питання задоволеності роботою органів місцевого самоврядування. Дані показники повинні формуватися на регіональному рівні. Показники першого блоку в числі інших застосовуються при оцінці ефективності діяльності органів місцевого самоврядування муніципальних районів (міських округів), другі - при оцінці ефективності адміністрацій міських та сільських поселень.

Крім переліку показників для оцінки ефективності організації надання муніципальних послуг населенню на регіональному рівні формується перелік показників для оцінки есрективності управління місцевим господарством і ефрективності управління комплексним соціально-економічним розвитком території в залежності від приналежності муніципального району (міського округу) до певного кластеру (території групуються по кластерам в залежності від їх соціально-економічного розвитку).

Відповідно до представленої методики на рівні муніципального району (міського округу) фрунк- 


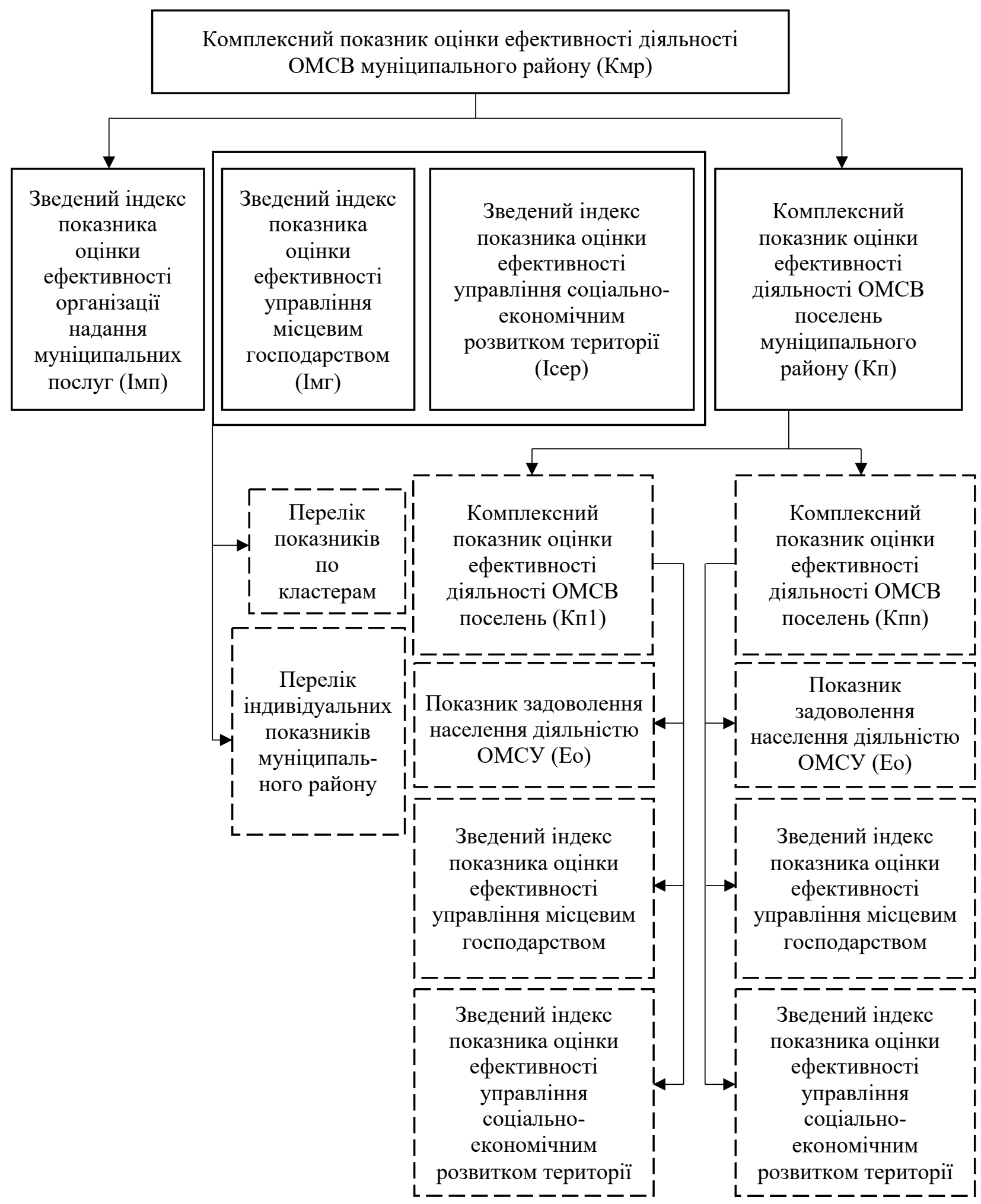

Рис. 2. Склад комплексного показника оцінки ефективності діяльності органів місцевого самоврядування

ціонує система індивідуальних показників, що складається з переліків показників оцінки ефективності управління місцевим господарством і показників оцінки ефективності управління соціально-економічним розвитком території.
Перший перелік показників фрормується 3 урахуванням слабких сторін фрункціонування місцевого господарства при попередньому порівняльному аналізі стану об'єкта оцінки в муніципальному районі (міському окрузі) зі 
середньо-регіональним значеннями. Другий перелік показників формується 3 урахуванням розроблених в муніципальному утворенні програмних документів 3 комплексного соціально-економічного розвитку території.

Необхідно відзначити, що число показників для оцінки ефективності управління місцевим господарством в муніципальному районі (міському окрузі) невелика, так як більша частина питань місцевого значення в даній сфрері перенесена на рівень поселення. Отже, розширення кола показників (з урахуванням питань місцевого значення міського округу) $€$ некоректним, оскільки оцінка стану об'єкта повинна відбуватися по ідентичним показниками. Таким чином, оцінка ефективності управління місцевим господарством включає в себе оцінку заходів 3 охорони навколишнього середовища, оцінку стану автомобільних доріг і стану соціальної інфрраструктури.

Висновки. В основі запропонованої методики розрахунку комплексного показника оцінки ефективності діяльності органів місцевого самоврядування лежить сукупність дисреренційованого і уніфрікованого підходу. Поєднання цих підходів, а також облік розвитку кожного поселення, що входить до складу муніципального району (міського округу), дозволить оцінювати діяльність органів місцевого самоврядування більш об'єктивно і буде сприяти усуненню слабких місць території, оскільки від цього залежить ефективність роботи місцевої влади.

\section{СПИСОК ВИКОРИСТАНИХ ДЖЕРЕЛ:}

1. Чернюк Л.Г. Місцеві органи влади в системі регіонального управління. Ефрективна економіка. 2014. № 2. URL: http://www.economy.nayka.com.ua/?op=1\&z=2779

2. Сидоренко Н. Ефеективність діяльності органів місцевого самоврядування у сфері міжнародного співробітництва. URL: http://www.dridu.dp.ua/vidavnictvo/2012/2012_01(12)/12snosms.pdf

3. Ведурн Е. Оцінювання державної політики і програм : навч. посіб. / пер. з англ. В.В. Шульга. Київ : Всесвіт, 2003. $350 \mathrm{c}$.

4. Бортник Н.П., Дніпров О.С. Проблеми оцінки якості та ефрективності діяльності органів виконавчої влади. Актуальні проблеми відчизняною юриспрунденції. 2017. № 6. Том 3. С. 80-84.

5. Михайлюк В.С. Ефективність діяльності органів місцевого самоврядування як запорука надання якісних послуг населенню. URL: http://intkonf.org/mihaylyuk-vs-efektivnist-diyalnosti-organiv-mistsevogosamovryaduvannya-yak-zaporuka-nadannya-yakisnih-poslug-naselennyu/

\section{REFERENCES:}

1. Chernyuk L.H. (2014) Mistsevi orhany vlady v systemi rehionalnoho upravlinnya [Local authorities in the system of regional government]. Efektyvna ekonomika, no. 2. URL: http://www.economy.nayka.com.ua/?op=1\&z=2779

2. Sydorenko N. (2012) Efektyvnist diyalnosti orhaniv mistsevoho samovryaduvannya u sferi mizhnarodnoho spivrobitnytstva [The effectiveness of local governments in the field of international cooperation]. URL: http://www.dridu.dp.ua/vidavnictvo/2012/2012_01(12)/12snosms.pdf

3. Vedurn E. (2003) Otsinyuvannya derzhavnoyi polityky i prohram: navch. posib. [Evaluation of public policy and programs: textbook. way] / per. z anhl. V.V. Shulha. Kyiv: Vsesvit, 350 p.

4. Bortnyk N.P., Dniprov O.S. (2017) Problemy otsinky yakosti ta efektyvnosti diyalnosti orhaniv vykonavchoyi vlady [Problems of assessing the quality and efficiency of executive bodies]. Aktualni problemy vidchyznyanoyu yurysprundentsiyi, no. 6, tom 3, pp. 80-84.

5. Mykhaylyuk V.S. Efektyvnist diyalnosti orhaniv mistsevoho samovryaduvannya yak zaporuka nadannya yakisnykh posluh naselennyu [Efficiency of local self-government bodies as a guarantee of providing quality services to the population]. URL: http://intkonf.org/mihaylyuk-vs-efektivnist-diyalnosti-organiv-mistsevogo-samovryaduvannya-yak-zaporuka-nadannya-yakisnih-poslug-naselennyu/ 